Investigations

\title{
The Influence of Bioorganic Preparations and Mineral Fertilizers to the Productivity and Quality of Beetroot in the Subsurface Irrigation in the South-East of Kazakhstan
}

\author{
${ }^{1}$ Temirzhan Yerkassovich Aitbayev, ${ }^{2}$ Bekzat Abiyevich Turegeldiyev, \\ ${ }^{1}$ Laura Abdireevna Buribayeva, ${ }^{1}$ Akbope Temirzhanovna Aitbayeva \\ and ${ }^{1}$ Birzhan Sultanuly Rakhymzhanov
}

${ }^{1}$ Kazakh Research Institute of Potato and Vegetable Growing, Republic of Kazakhstan, 040917, Nauryz Street 1, Kazakhstan

${ }^{2}$ Kazakh National Agrarian University,

Republic of Kazakhstan, 050010, Abai avenue, 8, Almaty City, Kazakhstan

Article history

Received: 31-10-2017

Revised: 09-11-2017

Accepted: 09-01-2018

Corresponding Author: Temirzhan Yerkassovich Aitbayev

Kazakh Research Institute of Potato and Vegetable Growing, Republic of Kazakhstan, 040917, Nauryz Street 1,

Kazakhstan

E-mail: aitbayevt@yandex.ru

\begin{abstract}
Vegetables are valuable sources of vitamins, organic acids and mineral salts. In Kazakhstan, the consumption rate of vegetables per person is $120 \mathrm{~kg}$ per year, where $8 \mathrm{~kg}$ is beetroot. Beetroot cultivated area is 7,000 hectares. The yield is 150,000 tons, and the demand is 144,000 tons. Beetroot is one of the most popular and all year round vegetable that used in food. Despite the high biological potential (40-50 t/ha), the yield of beetroot is low (20-22 t/ha). The main reasons are deterioration of soil fertility and mineral consumption of the crop. Along with the increase in the productivity of beetroot, it is also necessary to improve the quality, especially the ecological purity of the crop. There is carried out experiments on the effect of various bioorganic preparations and mineral fertilizers on the yield, quality and storing quality of beetroots in KazRIPaVG. The goal of the experiment is to increase the yield, quality and environmental cleanliness of the products. Research methods are generally accepted in vegetable growing and agrochemistry. There was found an increase in the productivity of the crop to $10.9-38.4 \%$. Also, there was noted improved quality and conservation of beetroot from many types of bioorganic fertilizers. Mineral fertilizers showed a high effect in subsurface irrigation. In addition, $15.6-46.3 \%$ of beetroot was obtained. The highest production ( $37.6 \mathrm{t} / \mathrm{ha}$ ) was provided by the fertilizer $\mathrm{N}_{150} \mathrm{P}_{90} \mathrm{~K}_{120}$.
\end{abstract}

Keywords: Beetroot, Bioorganic Preparations, Mineral Fertilizers, Subsurface Irrigation, Ecology, Yield, Quality, Storing Quality

\section{Introduction}

Vegetable farming is an important sector of agriculture in Kazakhstan that designed to provide balanced food to the population for the whole season. The soil and climatic conditions of the country allow producing large amount of various types of vegetables and thereby ensuring the domestic market completely. According to statistics in 2016, vegetables were cultivated in the area of 146.2 thousand hectares, and 3.564 million tons were harvested in Kazakhstan. The country supply by vegetables was $210 \%$ (Committee on Statistics of the Ministry of National Economy of the Republic of Kazakhstan).
The sown area of beetroot is about 7 thousand hectares $(5 \%)$ in Kazakhstan. Moreover, the gross harvest is 150 thousand tons with the demand of 144 thousand tons. Beetroot is the most popular and all yearround used vegetable in the country. Beetroot contains $18-24 \%$ of dry substances, $12-17 \%$ of sugar, and 13-15 $\mathrm{mg}$ of vitamin $\mathrm{C}$. Beetroot is unique in its content of biologically and physiologically active substances, and the caloric content is very high. It contains proteins, fats, fiber, pectins, sugars (sucrose, fructose, and glucose), organic acids (malic, citric, oxalic and folic), vitamins $\mathrm{C}$, B1, B2, P, PP, and minerals (sodium, potassium salts, calcium, iron, phosphorus, iodine, magnesium, cobalt and manganese). There are many substances that can 
destroy harmful substances and improve the metabolism and the cardiovascular system in the human body. The caloric content of beetroot is superior to compare with all other vegetables (Lukyanets, 1978; Autko, 2008).

New varieties of beetroot have a high biological potential (50-70 t/ha) (Borisov et al., 2012). However, the actual yield of the crop is low (20-22 $t / h a)$. The main reasons are the deterioration of soil fertility and mineral nutrition of the crop. It should be noted that irrigation erosion and irrigated water deficiency have the negative impact on the yield. Hence, there is necessitates the introduction of water-saving technologies. There are also the negative impacts, such as improperly used fertilizer application technologies and unbalanced introduction of minerals. Hence, it is necessary to eliminate the issues in order to increase beetroot productivity.

There is also necessary to improve the quality of beetroot and other vegetables, especially ensuring environmental safety, along with an increase in the yield. In many countries, it is acute an issue of producing natural and environmentally safe products. In this case, the developed countries have begun to introduce organic technologies for the production of organic products (Gosling and Shepherd, 2005; Kirchmann et al., 2007; Boyhan et al., 2009; Willer and Lernoud, 2016; Organic Farming in Germany, 2017; Grigoruk and Klimov, 2016). Beetroot belongs to a group of vegetables with a high nitrate-accumulating ability. The main factor affecting the level of nitrates in products is the use of fertilizers. Fertilizers act as the main agrochemical method for increasing the productivity of vegetables and determine the quality of the crop. Therefore, it is necessary to use environmentally safe fertilizer systems (Vendilo and Shabunina, 1989; Litvinov, 2008; Sizov and Lunev, 1991; Stepuro et al., 2008).

Taking into the consideration the above mentioned, the Kazakh Research Institute of Potato and Vegetable Growing conducted field experiments to study the effect of various types of bioorganic preparations and mineral fertilizers on the yield, quality, and storing quality of beetroot by using subsurface irrigation.

\section{Materials and Methods}

\section{Fields Details}

The research was carried out at the experimental fields of the Kazakh Research Institute of Potato and Vegetable Growing (KazRIPaVG) located in the foothill zone of the South-East of Kazakhstan and on the northern slope of the Zailiysky Alatau Mountains (1,0001,050 $\mathrm{m}$ above sea level).

The South-East Kazakhstan (Almaty region) is a large region of the country farming potatoes and vegetables.
The climate of the foothill zone of the South-East of Kazakhstan is sharply continental, characterized by large daily and annual variations in air temperature, cold winters and prolonged hot summers.

The air temperature reaches the minimum values in January $\left(-32-35^{\circ} \mathrm{C}\right)$, the average being $\left.6-14^{\circ} \mathrm{C}\right)$, the maximum values are in July $\left.\left(+37-43^{\circ} \mathrm{C}\right)\right)$, the average being $+22-25^{\circ} \mathrm{C}$ ). The warm period is $240-275$ days, and the frost-free period is $140-170$ days. The sum of positive temperatures (above $0^{\circ} \mathrm{C}$ )) is $3,450-3,750^{\circ} \mathrm{C}$ ), and the sum of active temperatures (above $10^{\circ} \mathrm{C}$ )) $\left.3,100-3,400^{\circ} \mathrm{C}\right)$.

The relative air humidity reaches its maximum in winter $(85-90 \%)$ and minimum in summer $(35-40 \%)$. On average, in the warm period it is within $50-60 \%$.

The hydrothermal coefficient is $0.7-1.0$. The annual amount of precipitation is $350-600 \mathrm{~mm}$, during the warm period 120-200 $\mathrm{mm}$.

The soil cover of the foothill zone of the South-East of Kazakhstan is represented by the most diverse types of soils (chernozem, chestnut, serozem).

The soil of the experimental fields of KazRIPaVG is dark chestnut and medium loamy. The soil layer contains $2.9-3.0 \%$ humus, $0.18-0.20 \%$ of total nitrogen, and 0.19 $0.20 \%$ of total phosphorus. The content of P2O5 is $30-40$ $\mathrm{mg} / \mathrm{kg}$ soil, and $\mathrm{K}_{2} \mathrm{O}$ is $350-390 \mathrm{mg} / \mathrm{kg}$. The cation exchange capacity is $20-21 \mathrm{meq}$. per $100 \mathrm{~g}$. The reaction of the soil solution is slightly alkaline $(\mathrm{pH} 7.3-7.4)$. The volumetric mass of the soil is $1.1-1.2 \mathrm{~kg} / \mathrm{cm}^{3}$, and the lowest moisture capacity is $26.6 \%$. As a result of longterm use (more than 60 years) in irrigated vegetable farming, dark chestnut soils underwent a significant change in the basic parameters of fertility.

\section{Sample Preparation and Analytical Methods}

In the field experiments and laboratory studies, classical methods were used: agrochemical methods for studying soils (1975); method of agrochemical research (Yudin, 1980); method of field experiment; experimental methodology in vegetables and melon growing (edited by Belik, 1992). (Yudin, 1980; Armorov, 1985; Belik, 1992).

Methods for identification of the qualitative indicators of beetroot: dry matter - weight method (drying); total sugar - according to Bertrand; vitamin C - according to Murray; nitrates - by potentiometry using ion-selective electrodes.

Objects of research: beetroot, bioorganic fertilizers (Gumi K, Izobion, Atonic, Sok Zemlya, Rezfri, biohumus, MERS, Biosok), mineral fertilizers, and drip irrigation.

Below is a brief description of bioorganic fertilizers:

Gumi K (Kazakhstan) is 30\% water pasta. It contains humates of sodium not less than $60 \%$, macronutrients sodium $(0,5-2,0 \%)$, phosphorus $(0,5-2,0 \%)$, potassium $(0,1-1,0 \%)$ and microelements of natural origin. 
Izobion (Switzerland) is a new generation of biological fertilizer and a plant growth biostimulator. The active substance is amino acids and peptides $(62.50 \%)$.

Atonic (Japan) is biostimulant, regulator of growth and fruiting with pronounced regenerative and anti-stress effect. The active substance is sodium 5-nitroglyconate 3 $\mathrm{g} / \mathrm{l}+$ sodium orthonitrophenolate $6 \mathrm{~g} / \mathrm{l}+$ sodium paranitrophenolate $9 \mathrm{~g} / \mathrm{l}$.

Sok Zemlya (Russia) is a water extract from biohumus, which preserves its richest microbiological component. It contains dissolved components of humus and microflora in water that characteristic of pure chernozems, including cellulose-destroying fungi, lithotrophic microorganisms, lactic acid bacteria, nitrogenfixing bacteria and destructors of nitrogenous compounds.

Rezfri (Turkey) is a natural, certified organic biostimulator without chemical additives. It contains enzymes that divide carbohydrate molecules into oligosaccharide molecules. Oligosaccharides have the ability to stimulate root growth. Also, oligosaccharides are molecules that capture the moisture of air and keep it in the leaves of plants, thereby protecting them from drought.

Biohumus (Kazakhstan) is an organic fertilizer obtained in the process of processing organic waste by earthworms. Biohumus is a $100 \%$ natural product with a rich and diverse composition. The main components of biohumus are humus $(40 \%)$, nitrogen $(3 \%)$, potassium $(1.2 \%)$, phosphorus $(5 \%)$, calcium $(5 \%)$, and magnesium $(5 \%)$. In addition, biohumus contains microelements, such as boron, manganese, copper and zinc. Also, there are many humic substances, growth stimulants and enzymes.

MERC (Kazakhstan) is a new generation of microbiopreparations based on compounds of chlorophyll-vitamin-phytoncide composition of plants and microelements (Fe, $\mathrm{Mo}, \mathrm{Cu}, \mathrm{Zn}, \mathrm{Mn}, \mathrm{Co}, \mathrm{B})$. It has highly effective means of increasing crop yields and creates favorable conditions for reproduction of soil microorganisms that translate into the form (salt) assimilated for plants more than 19 macro and micro elements, providing plants with a balanced diet of $100 \%$.

Biosok (Kazakhstan) is a new complex microbiological organomineral humic fertilizer, biostimulator of growth, plant protection and development. Biosock is produced by red earthworms. Enriched with nitrogen and potassium, extract of biohumus contains humins, fulvic acids, phytohormones, antibiotic compounds, a complex community of microelements and microorganisms (metabolic products of earthworms) that revive the fertility of without fertilizers.

In the field experiments, mineral fertilizers have been studied in order to compare with bioorganic fertilizers and determine the efficiency in the subsurface irrigation system. From nitric fertilizers used ammonium nitrate $(34.5 \%$ a.i. N), from phosphoric used double superphosphate $\left(46 \%\right.$ a.i. $\left.\mathrm{P}_{2} \mathrm{O}_{5}\right)$, and from potassium used potassium chloride $\left(60 \%\right.$ a.i. $\left.\mathrm{K}_{2} \mathrm{O}\right)$.

The area of the experimental plot is $35 \mathrm{~m}^{2}(3.5 \mathrm{~m} \times$ $10 \mathrm{~m})$, the repetition of the experiments is 4 -fold.

In the field experiments with subsurface irrigation of beetroot, Kazakhstani irrigation pipes, produced by KazKauchuk LLP, were used.

Also, in the experiment was used a variety of beetroot "Kyzylkoner" which product of KazRIPaVG.

Agrotechnics of beetroot production in the field experiments is common for the foothill zone of the SouthEast of Kazakhstan, carried out in accordance with the recommendations of the KazRIPaVG for farmers.

\section{Results and Discussion}

In the Republic of Kazakhstan, vegetables are cultivated only by irrigated methods. In this regard, a huge attention is paid to the productivity of vegetable plantations. In the foothill zone of the South-East of the country, each hectare of irrigated land is of great value, where high-fertile soils and sufficient water resources are concentrated. Therefore, all new developed scientific methods, such as selection achievements (varieties) and technological developments (agrotechnologies) should be aimed at increasing the productivity of vegetables. The yield of vegetables remains the main indicator of the effectiveness of agricultural technologies. Taking this into account, we determined the yield of beetroot, depending on the various types of bioorganic fertilizers in studies on the development of an ecologically safe system for fertilizing beetroot.

Experimental data have shown that under the influence of the applied preparations (bioorganic fertilizers), the productivity of beetroot is significantly increased. At the same time, their different effects on beetroot yield levels were conducted (Table 1).

In the control plot, where beetroot was grown without fertilizers, the yield was on average $24.85 \mathrm{t} /$ ha which was not high for 2 years. The lower yield of the plot is due to the deterioration of the conditions for the nutrition of beetroot which affect by the absence of fertilizers. This plot plants were poorly provided with nutrients.

In beetroot, the introduction of full mineral fertilizers into the soil in norm $\mathrm{N}_{160} \mathrm{P}_{120} \mathrm{~K}_{200}$ (fertilized control) promoted the formation of a relatively high crop yield. The average of $35.7 \mathrm{t} / \mathrm{ha}$ of beetroot yield was obtained, which is $43.66 \%$ higher than pure control (without fertilizers). Therefore, the norm of fertilizer with the main macro elements recommended by KazRIPaVG significantly improves the nutrition of plants and increases the yield of beetroot to $10.85 \mathrm{t} / \mathrm{ha}$. This shows the high responsiveness of beetroot to the introduction of mineral fertilizers. 
Table 1: The effect of bioorganic fertilizers on the yield of beetroot

\begin{tabular}{|c|c|c|c|c|c|}
\hline \multirow[b]{2}{*}{ Experiment variants } & \multicolumn{3}{|c|}{ Average harvest of beetroot, $\mathrm{t} / \mathrm{ha}$} & \multicolumn{2}{|c|}{ Additional yield } \\
\hline & 2015 & 2016 & Average & $\mathrm{t} / \mathrm{ha}$ & $\%$ \\
\hline Control (without fertilizers) & 24,1 & 25,6 & 24,85 & - & - \\
\hline $\mathrm{N}_{160} \mathrm{P}_{120} \mathrm{~K}_{200}$ (control with fertilizers) & 35,4 & 36,0 & 35,70 & 10,85 & 43,66 \\
\hline Gumi $\mathrm{K}+\mathrm{N}_{60}$ & 28,2 & 29,3 & 28,75 & 3,90 & 15,69 \\
\hline Izabion, 4 1/ha & 27,5 & 28,7 & 28,10 & 3,25 & 13,08 \\
\hline Atonic, $0,2 \mathrm{l} / \mathrm{ha}$ & 28,6 & 30,6 & 29,60 & 4,75 & 19,11 \\
\hline Sok Zemlya, 14 1/ha & 26,9 & 28,2 & 27,55 & 2,70 & 10,87 \\
\hline Rezfri, 4 1/ha & 30,3 & 31,1 & 30,70 & 5,85 & 23,54 \\
\hline Biohumus, $4 \mathrm{t} / \mathrm{ha}$ & 34,3 & 34,5 & 34,40 & 9,55 & 38,43 \\
\hline MERS, 1 1/ha & 29,7 & 30,4 & 30,05 & 5,20 & 20,93 \\
\hline $\begin{array}{l}\text { Biosok, } 5 \text { l/ha } \\
\text { m, \% 2,35 2,45 } \\
\text { md095, t/ha 2,94 2.74 }\end{array}$ & 28,0 & 29,8 & 28,90 & 4,05 & 16,30 \\
\hline
\end{tabular}

Bioorganic fertilizers showed lower effect compare to mineral control. Only in the variant with biohumus, a significant yield of beetroot was obtained, which was $34,40 \mathrm{t} / \mathrm{ha}$. A small difference $(1.30 \mathrm{t} / \mathrm{ha})$ compared to version $\mathrm{N}_{160} \mathrm{P}_{120} \mathrm{~K}_{200}$ is within the error of experience. This can be explained that biohumus is a valuable and complex organic fertilizer containing all the important macro and micro elements for plant growth.

In experiment variants with other types of bioorganic fertilizers, the yield of beetroot was significantly lower than the variant with mineral fertilizer. This is affected by deficiency of nutrition in plants, because new biopreparations do not contain all the elements, and they are in limited quantities. At the same time, all bioorganic fertilizers had a positive effect on the crop productivity. When they were used, significant increases in the yield of beetroot were achieved. When Gumi $\mathrm{K}+\mathrm{N}_{60}$ was applied, $28.75 \mathrm{t} / \mathrm{ha}$ of beetroot yield was obtained, which is higher than the unfertilized control by 3.90 t/ha or $15.69 \%$. Izobion preparation increased the yield of beetroot by $3.25 \mathrm{t} / \mathrm{ha}$, which is higher than the unfertilized control to $13.08 \%$. In the plot with Atonic preparation, $29.60 \mathrm{t} / \mathrm{ha}$ of beetroot yield was taken, and this is more than the unfertilized control by $4.75 \mathrm{t} / \mathrm{ha}$ (19.11\%). Among bioorganic fertilizers, the minimum yield was obtained on the variant with Sok Zemlya $(27.55 \mathrm{t} / \mathrm{ha})$ and the maximum yield was on the variant with Rezfri (30.70 t/ha) with yield growth 10.87 and 23.54\%. When used MERS and Biosok, it was received $30.05 \mathrm{t} / \mathrm{ha}$ and $28.90 \mathrm{t} / \mathrm{ha}$ of yield, respectively. The additional yield from these preparations was $5.20 \mathrm{t} / \mathrm{ha}$ and $4.05 \mathrm{t} / \mathrm{ha}$ or $20.93 \%$ and $16.30 \%$.

According to experience, the productivity of beetroot was increased by $10.87-23.54 \%$. This proves the great promise of biopreparations for vegetable production.

In vegetable production, a quality of the fruit is very important, since they have a direct impact on the people's health. Vegetables, as the main source of vitamins, make up a valuable part of a human's daily diet. A variety of vegetable products are required daily for a balanced diet. Vegetables are used mainly for fresh or after shallow processing. Therefore, vegetables should be environmentally safe, not to harm the human body with toxic residues, and with high-vitamins, which vegetables are valued. It should be also to take into account the fact that high quality and environmentally safe raw materials are required for the processing industry for the production of canned vegetables.

When testing various types of bioorganic fertilizers, as well as increasing rates of mineral fertilizers in the system of subsurface irrigation, we tested biochemical analyzes of the yield of beetroot considering the importance of the quality of vegetables for fresh and processing uses.

It is conducted that the mineral nutrition has a significant effect on the biochemical composition of the products. An improvement in the quality of beetroot on variants with bioorganic fertilizers was noted (Table 2). The content of dry substances, sugars and vitamins increased in the crop by using many types of bio preparations. In some cases, a slight decrease in individual qualitative indicators of beetroot was observed in the analyzes.

In the unfertilized control, beetroot contained on average $20.8 \%$ of dry matter, $12.98 \%$ of total sugar, and $16.50 \mathrm{mg}$ of vitamin C. In the fertilized control with application of $\mathrm{N}_{160} \mathrm{P}_{120} \mathrm{~K}_{200}, 21.29 \%$ of dry matter, $12,10 \%$ of total sugar and $18.90 \mathrm{mg} \%$ of ascorbic acid (vitamin C) was contained. In the five field experiments with biopreparations from eight of the studied showed an increase in dry matter $(20.92-22.20 \%)$. A valuable indicator of beetroot is the content of sugars. Rezfri and Biohumus had a favorable effect on the accumulation of total sugar in beetroot by containing $13.35 \%$ and $13.20 \%$ of total sugar, respectively. On the variant with bio preparation Atonic, a considerable amount of sugars was also accumulated in the production, which was $12.90 \%$. 
Table 2: The effect of bioorganic fertilizers on the quality of beetroot

\begin{tabular}{lcccr}
\hline Experiment variants & Dry matter (\%) & Total sugar (\%) & Vitamin C (mg\%) & Nitrates $(\mathrm{mg} / \mathrm{kg})$ \\
\hline Control (without fertilizers) & 20,80 & 12,98 & 16,50 & 106 \\
$\mathrm{~N}_{160} \mathrm{P}_{120} \mathrm{~K}_{200}$ (control with fertilizers) & 21,29 & 12,10 & 18,90 & 97 \\
Gumi K+N $+\mathrm{N}_{60}$ & 20,37 & 12,13 & 21,25 & 148 \\
Izabion, 4 1/ha & 21,75 & 10,93 & 18,44 & 105 \\
Atonic, 0,2 1/ha & 21,62 & 12,90 & 16,05 & 104 \\
Sok Zemlya, 14 1/ha & 22,20 & 11,70 & 18,44 & 82 \\
Rezfri, 4 1/ha & 22,01 & 13,35 & 15,40 & 81 \\
Biohumus, 4 t/ha & 20,92 & 13,20 & 20,24 & 61 \\
MERS, 1 1/ha & 17,98 & 10,33 & 22,23 & 78 \\
Biosok, 5 1/ha & 19,86 & 10,13 & 16,71 & 70 \\
\hline
\end{tabular}

Table 3: Storing quality of beetroots in the long-term storage depending on the types of bioorganic fertilizers (2015-2016 and 2016-2017)

\begin{tabular}{|c|c|c|c|c|}
\hline \multirow{2}{*}{$\begin{array}{l}\text { Experiment } \\
\text { variants }\end{array}$} & \multirow{2}{*}{$\begin{array}{l}\text { Storing quality of } \\
\text { beetroot during } \\
\text { storage, } \%\end{array}$} & \multirow{2}{*}{$\begin{array}{l}\text { Total losses during } \\
\text { the storing of beetroot } \\
\text { in storage, } \%\end{array}$} & \multicolumn{2}{|l|}{ Including } \\
\hline & & & Natural mass loss & Affected by disease \\
\hline Control (without fertilizers) & 88,05 & 11,95 & 8,35 & 3,60 \\
\hline $\mathrm{N}_{160} \mathrm{P}_{120} \mathrm{~K}_{200}$ (control with fertilizers) & 89,05 & 10,95 & 8,10 & 2,85 \\
\hline Gumi $\mathrm{K}+\mathrm{N}_{60}$ & 88,05 & 11,95 & 8,10 & 3,85 \\
\hline Izabion, 4 1/ha & 87,80 & 12,20 & 8,65 & 3,55 \\
\hline Atonic, $0,21 / \mathrm{ha}$ & 90,65 & 9,35 & 7,60 & 1,75 \\
\hline Sok Zemlya, 14 1/ha & 87,40 & 12,60 & 8,50 & 4,10 \\
\hline Rezfri, 4 l/ha & 88,80 & 11,20 & 7,70 & 3,50 \\
\hline Biohumus, 4 t/ha & 91,05 & 8,95 & 7,45 & 1,50 \\
\hline MERS, 1 l/ha & 89,95 & 10,05 & 7,80 & 2,25 \\
\hline Biosok, 5 l/ha & 89,90 & 10,10 & 7,75 & 2,35 \\
\hline \multirow{2}{*}{\multicolumn{5}{|c|}{$\mathrm{m}, \% 0,54-0,75$}} \\
\hline & & & & \\
\hline
\end{tabular}

The content of vitamin $\mathrm{C}$ on fertilized control was 16.50 $\mathrm{mg} \%$, while the NPK had $18.90 \mathrm{mg} \%$. In five variants of the experiment with Gumi K, Izobion, Sok Zemlya, Biohumus and MERC, sugar content was noticeably higher (2.0-6.7 mg \%) compared to unfertilized control and the level of ascorbic acid was superior to mineral control. In other variants with biopreparations, the content of vitamin $\mathrm{C}$ was at the control level, and the quality of products has not deteriorated.

The nitrates in vegetables are an acute environmental problem in the vegetable production. In the human body, almost $70-80 \%$ of the daily norm of nitrates comes from vegetables. Therefore, the production of vegetables with low and permissible levels of nitrates is of great importance. Considering this, we analyzed the yields of beetroot grown with different preparations. According to the analysis, the content of nitrates in beetroots was 1020 times lower than the permissible standards (MPC for beetroot is $1400 \mathrm{mg} / \mathrm{kg}$ ). This makes possible to consider that the products are absolutely clean for this environmental indicator.

In the vegetable production, storing quality is very important. Since, after the completion of the growing season and harvesting of the crops, it becomes necessary to store them in the storage for the long-term to provide consumers during the whole season.
Taking into consideration all above mentioned, we have studied the effect of new bioorganic fertilizers on the storing quality of beetroots during the long-term storage.

The research was carried out in the vegetable storage of KazRIPaVG. The results of experiments on storing beetroot for 7 months in two storage seasons (2015-2016 and 2016-2017) are shown in Table 3.

In the experiments, the positive effect of fertilizers on the storing quality of beetroot was noted. In all variants, the storing quality of the product was higher than control.

In the unfertilized variant (control-1), an average $88.05 \%$ of beetroot in the storage was saved in two study seasons after 7 months (October-April). At the same time, the total losses were $11.95 \%$ from $8.35 \%$ fell to natural weight loss and $3.60 \%$ to disease-affected.

In the variant with mineral fertilizers with the norms of $\mathrm{N}_{160} \mathrm{P}_{120} \mathrm{~K}_{200}$ (fertilizer control-2) recommended by the KazRIPaVG remained at $89.05 \%$. The total loss was $10.95 \%$, including the natural loss of $8.10 \%$ and by diseases $2.85 \%$. In variants with the use of various types of bioorganic fertilizers, storing quality of beetroots was $87.40-91.05 \%$, respectively. The comparatively higher percentage was in the variant with Biohumus, and this variant also treated with Atonic. 
Table 4: Yield and quality of beetroots when applying different norms of mineral fertilizers in subsurface irrigation (2015-2016)

\begin{tabular}{|c|c|c|c|c|c|}
\hline \multirow{2}{*}{$\begin{array}{l}\text { Norm of mineral } \\
\text { fertilizers }\end{array}$} & \multirow{2}{*}{$\begin{array}{l}\text { Yield of } \\
\text { beetroot }(\mathrm{t} / \mathrm{ha})\end{array}$} & \multicolumn{4}{|c|}{ Quality indicators of beetroot } \\
\hline & & Dry content $(\%)$ & Total sugar (\%) & Vitamin C (mg \%) & Nitrate $(\mathrm{mg} / \mathrm{kg})$ \\
\hline $\mathrm{N}_{0} \mathrm{P}_{0} \mathrm{~K}_{0}$ & 25,7 & 19,56 & 11,40 & 18,05 & 108 \\
\hline $\mathrm{N}_{50} \mathrm{P}_{30} \mathrm{~K}_{40}$ & 29,7 & 17,92 & 11,87 & 19,47 & 92 \\
\hline $\mathrm{N}_{100} \mathrm{P}_{60} \mathrm{~K}_{80}$ & 33,5 & 19,13 & 11,42 & 16,50 & 102 \\
\hline $\mathrm{N}_{150} \mathrm{P}_{90} \mathrm{~K}_{120}$ & 37,6 & 17,97 & 12,13 & 13,49 & 117 \\
\hline \multirow{2}{*}{\multicolumn{6}{|c|}{$\begin{array}{l}\mathrm{m}, \% 2,15 \\
\mathrm{md} 095, \mathrm{t} / \mathrm{ha} 1,50-2.98\end{array}$}} \\
\hline & & & & & \\
\hline
\end{tabular}

According to experiment, the storing quality of beetroots was quite high. If the natural loss of beetroot during the long-term storage was $7.45-8.65 \%$, which is inevitable as a natural, the disease losses within 1.50$4.10 \%$ are low within the permissible norms.

Thus, the new bioorganic fertilizers have positive effects to beetroot during the long-term storage.

In Kazakhstan, new progressive water saving technologies for irrigating crops is being introduced every year. Currently, drip irrigation and sprinkling are introduced on an area of more than 50 thousand hectares. This is about $3 \%$ of the land used in irrigated agriculture. A new method of irrigation is subsurface irrigation. This technology is completely new for our republic and requires study in irrigated crops, in particular vegetables (Kalashnikov et al., 2014).

In 2015-2016, experiments were conducted to study the effectiveness of technology for subsurface irrigation of vegetable crops in comparison with traditional irrigation in KazRIPaVG. The yield of beetroot in the variant with traditional irrigation method was an average of $31.3 \mathrm{t} / \mathrm{ha}$ in two years of research, and in the variant with subsurface irrigation system was $37.6 \mathrm{t} / \mathrm{ha}$. There was an additional $6.3 \mathrm{t} /$ ha yield or $20.1 \%$ due to the new irrigation method. This became possible due to the uniform supply of beetroots with water, the creation of an optimal water-air regime in the soil, and the improvement of the phytosanitary conditions of the field.

Along with study of two irrigation methods, we also studied the movement of mineral nutrition in the subsurface irrigation. The results of the studies showed that high efficiency of all norms of mineral fertilizers (Table 4). Thus, single norms of NPK fertilizers increased the yield of beetroots by $15.6 \%$, double standards by $30.4 \%$ and triple norms by $46.3 \%$. The most effective was the norm $\mathrm{N}_{150} \mathrm{P}_{90} \mathrm{~K}_{120}$.

In this experiment, the productivity and the qualitative indicators of beetroot yield were also studied. The data of biochemical analyzes show that the quality of the products also differs depending on the conditions of plant nutrition. The quality of beetroot was better with moderate mineral nutrition, and the crop contained more solids and vitamins. Application of higher norms of NPK-fertilizers slightly reduced the content of dry substances and vitamin $\mathrm{C}$, while increasing the sugar content of beetroot. The content of nitrates in beetroot was 10-12 times lower than the MPC, which means that the products are environmentally safe.

\section{Conclusion}

Based on the results of the research, the following conclusions are given.

All the new bioorganic fertilizers had a positive effect on the formation of beetroot. The beetroot yield increased by $10.87-38.43 \%$. The most effective was Biohumus. Biologically active preparations, such as Rezfri, MERC, Atonic and Biosok are promising for use in the crop production.

The mineral nutrition has a significant effect on the quality of beetroot. The content of dry substances, sugars and vitamins increased in beetroot by using biopreparations. The best quality indicators of production were noted when using Biohumus, Atonic and MERC.

New bioorganic fertilizers improved the storing quality of beetroot during the long-term storage. 88.80$91.05 \%$ of beetroot stay fresh after 7 month of storing in the storage. In this case, a relatively high storing quality of the crop was noted in the variants, where Biohumus and Atonic were used.

Biopreparations, such as Biohumus, Rezfri, Gumi K, Izobion, Sok Zemlya and Biosok contribute to get the environmentally safe products.

All studied bioorganic fertilizers were effective on beetroot and have a perspective for use in the crop production.

Mineral fertilizers show a high effect when applied to beetroot in subsurface irrigation. The largest yield of beetroot $(37.6 \mathrm{t} / \mathrm{ha})$ was obtained on the variant $\mathrm{N}_{150} \mathrm{P}_{90} \mathrm{~K}_{120}$, where the productivity of the crop increased by $46.30 \%$.

\section{Acknowledgement}

The scientific research was carried out by the team from the department of the technology of cultivation and seed production of vegetables, the laboratory of agrochemistry, and research workers and technical personnel in the framework of scientific programs of KazRIPaVG. In addition to the authors of this scientific article, the researches were conducted by Mamyrbekov Z.Z., Toilybaeva N.N., Aitbaeva B.U., Seidazimova 
D.A., and Balgabayev R.K. We express great gratitude to our colleagues for their active participation, significant contribution to conducting field experiments and laboratory studies, and obtaining experimental data.

\section{Author's Contributions}

All authors equally participated in all experiments, coordinated the data-analysis and contributed to the writing of the manuscript.

\section{Ethics}

This article is original and contains unpublished material. The corresponding author confirms that all of the other authors have read and approved the manuscript and there are no ethical issues involved.

\section{References}

Armorov, B.A., 1985. Methodology of Field Experience. Moscow, pp: 420.

Autko, A.A., 2008. Vegetables in human nutrition. Minsk: "Science".

Belik, V.F., 1992. Technique of the Experimental Business in Vegetable Growing and MelonGrowing. Moscow, pp: 320.

Borisov, V.A., A.V. Romanova, S.A. Maslovsky and S.A. Andrianov, 2012. Varietal peculiarities of growing and storage of table beets. Potatoes Vegetables, 4: 22-24.

Boyhan, G.E., W.T. Kelley, D.B. Langston, A.N. Sparks and S. Culpepper et al., 2009. Commercial organic vegetable production. The University of Georgia.

Committee on Statistics of the Ministry of National Economy of the Republic of Kazakhstan, 2017. http://www.stat.gov.kz

Gosling P. and M. Shepherd, 2005. Long-term changes in soil fertility in organic arable farming systems in England, with particular reference to phosphorus and potassium. Agriculture Ecosystems Environment, 105: 425-432.

DOI: $10.1016 /$ j.agee.2004.03.007

Grigoruk, V.V. and E.V. Klimov, 2016. The development of organic agriculture in the world and Kazakhstan. Ankara.

Kalashnikov, A.A., P.A. Kalashnikov and A.E. Baizakova, 2014. Water saving technology of subsurface irrigation of beetroot. Science World, 11: 66-69.
Kirchmann, H., L. Bergstro, T. Katterer, L. Mattsson and S. Gesslein, 2007. Comparison of long-term organic and conventional crop-livestock systems on a previously nutrient-depleted soil in Sweden. Agron. J., 99: 960-972. DOI: 10.2134/agronj2006.0061

Litvinov, S.S., 2008. Scientific foundations of modern vegetable growing. Moscow: VNIIO.

Lukyanets, A.N., 1978. Directory of vegetable grower. Alma-Ata: "Kainar".

Organic Farming in Germany, 2017. www.bmel.de/EN/Agriculture/SustainableLandUse/ Texte/OrganicFarmingInGermany.html

Sizov, A.P. and M.I. Lunev, 1991. Influence of mineral nutrition on the content of nitrates in beetroots. Agrochemistry, 4: 40-44.

Stepuro, M.F., I.P. Dobrovolskaya, G.L. Titko and A.A. Vorobiev, 2008. Influence of doses of simple and complex mineral fertilizers in vegetable-fodder crop rotation on yield and quality of beetroot. VegetableGrowing, pp: 139-141.

Vendilo, G.G. and T.G. Shabunina, 1989. Influence of mineral fertilizers on productivity and quality of table beet. Chemicalization Agriculture, 3: 33-35.

Willer, H. and J. Lernoud, 2016. The world of organic agriculture. Statistics and Emerging Trends 2016. Research Institute of Organic Agriculture FiBL and IFOAM Organics International, pp: 1-336.

Yudin, F.A., 1980. Methodology of agrochemical research. Moscow.

\section{Abbreviations}

KazRIPaVG - Kazakh Research Institute of Potato and Vegetable Growing

$\mathrm{N}$ - nitrogen

$\mathrm{P}$ - phosphorus

$\mathrm{K}$ - potassium

$\mathrm{t}-$ ton

ha - hectare

$\mathrm{t} /$ ha - ton per hectare

kg - kilogram

g - gram

$\mathrm{mg}$ - milligram

$\mathrm{m} 2$ - square meter

$\mathrm{mg} \%$ - milligram/percentage

$\%$ - percentage

MPC - maximum permissible concentration 